\title{
The Pseudo-Judiciary to Increase Investor Interest in the Settlement of Tax Disputes in Indonesia Case Study of PT ABC Jakarta
}

\author{
Imam Nashirudin ${ }^{1}$, Faisal Santiago ${ }^{2}$ \\ Doctor of Law Program Student, Borobudur University, Jakarta, Indonesia ${ }^{1}$, Borobudur \\ University, Faculty of Law, Jakarta, Indonesia ${ }^{2}$ \\ \{Imam.nashirudin@gmail.com ${ }^{1}$, faisalsantiago@borobudur.ac.id² $\}$
}

\begin{abstract}
In the implementation of tax regulations there are often tax disputes between taxpayers and tax officers. Tax disputes usually arise due to differences in interpretation between taxpayers and tax authorities or differences in views over evidence found in the field. Tax disputes can occur at various levels. After the submission of the Annual Tax Return, usually the tax authority will conduct a test of the tax report submitted by the taxpayer through a tax check. The results of the examination may cause disputes if the taxpayer does not agree with the results of the examination. The research in this paper is a legal research that is precritative and applied. The source of the material used is primary legal material and secondary technical legal material, through library/document studies, interconnected legal analysis techniques for conclusion. The purpose of this research is to find out the legal efforts that taxpayers must take to resolve tax disputes in Indonesia before appealing to the tax tribunal. Tax disputes are resolved at the objection level but if the taxpayer has not been able to accept the result then the tax dispute proceeds to the appeal level in the Tax Tribunal. The research in this paper is a legal research that is precritative and applied. The source of the material used is primary legal material and secondary technical legal material, through library/document studies, interconnected legal analysis techniques for conclusion. The purpose of this research is to find out the legal efforts that must be taken by the taxpayer to resolve the DISPUTE of PT ABC with the tax officer before appealing to the tax tribunal.
\end{abstract}

Keywords: The Pseudo-Judiciary; Tax Disputes; Increase Investor; Investor Interest

\section{Introduction}

Tax is the mandatory dues of every citizen who in its implementation can be imposed. Tax has an important and critical position in our country because it plays an $83 \%$ role in the State Budget. Taxes are the primary fund supplier to finance our country's operations. In order to collect tax money for the state, the Directorate General of Taxation conducts a series of routine activities to monitor and test the compliance of tax payments. Compliance testing is usually done by inspection. At the time of the inspection, it is often found that new data is not 
indisputable and must be paid for by the taxpayer, but it does not close the possibility of differences of opinion between the tax officer and the taxpayer. Data discrepancies and differences in interpretation of provisions lead to disputes. Settlement of tax disputes can be done through various levels. First, taxpayers object to the regional office of the tax assessment issued by the KPP. If the objection decision is unsatisfactory, taxpayers can appeal to the Tax Tribunal. If the appeal decision is not satisfactory, taxpayers can make an extraordinary effort in the form of filing a Review to the Supreme Court

\section{Case Study}

PT ABC is examined by the KPP, because its SPT shows more pay and taxpayers ask for VAT restitution. In the examination it is known that, taxpayers should not have an overpayment. In the examination is known, there is a underpayment of Rp 200 million. On the findings, fiscus issued a tax assessment in the form of VAT SKPKB of Rp 200 million.

The decision has raised objections. Taxpayers argue that they have performed their tax obligations properly and for overpayment of their taxes, feel entitled to request a refund through the restitution mechanism.

\section{Discussion}

To resolve a tax dispute, taxpayers cannot directly appeal to the Tax Tribunal. Taxpayers must first submit objections to the KPP boss's office (Regional Tax office) to resolve the disputed issue. In Law No. 6 of 1983 as amended last by Law Number: 16 of 2019 concerning General Provisions and Procedures of Taxation (KUP Law), there are articles governing the rights and obligations of taxpayers. One of the taxpayer's rights is the right to object. The provisions on objections are in Article 25 of the KUP Law. In Article 25 paragraph (1) of the KUP Law, sufficient tax objections can be interpreted as efforts that can be taken by taxpayers who do not agree with the results of the examination contained in the tax assessment or on the withholding or collection of taxes by third parties.

Filing objections to tax authority provisions is commonplace. Therefore, to ensure justice for taxpayers, the KUP Law gives the right to object to the results of the examination. In the settlement of tax disputes through these objections, DJP is often referred to as a pseudojudiciary (Soemitro, 1991). The objection process gives taxpayers the opportunity to prove that the tax assessments issued contain elements of wrong doing This opportunity is given by considering the principle of fairness for taxpayers on the one hand and tax institutions on the other.

Objections can only be submitted to the Director General of Taxation for: Underpayment Tax Assessment Letter (SKPKB); Additional Underpayment Tax Assessment Letter (SKPKBT); Overpayment Tax Assessment Letter (SKPLB); Zero Tax Assessment Letter (SKPN); Or Withholding or collection of taxes by third parties based on the provisions of tax legislation. In accordance with Article 1 of the KUP Law, SKPKB is a tax assessment letter that determines the amount of tax that is still to be paid. Meanwhile, SKPKBT is a tax assessment letter that determines the additional amount of tax that has been determined. The emergence of this provision is usually due to the existence of new data that has not been revealed at the time of the previous examination in the tax year in question. SKPLB is a tax assessment letter that determines the amount of overpayment of tax should not be owed. 
SKPN is a zero tax assessment letter Objections can also be raised against deductions or tax collections made by third parties as tax cutters. Furthermore, in accordance with Article 2 paragraph (3) of Regulation of the Minister of Finance (PMK) No. 202/PMK,03/2015 concerning Amendment to PMK No. 9/PMK.03/2013 concerning Procedures for Submission and Settlement of Objections, taxpayers can only object to the material or content of the tax assessment letter. The materials and contents in question include the amount of loss based on the provisions of tax legislation, the amount of tax, or the material or content of withholding or collection of taxes. Then, it is also affirmed in Article 2 paragraph (4) PMK 202/2015, if there is a reason for objection other than the material or content of the tax assessment letter or withholding or tax collection, the reason is not considered in the settlement of objections.

The first step, taxpayers should send a letter of objection to the regional office of the Directorate General of Taxation of KPP superiors who conduct the examination. Objections are raised to the tax assessments set by the KPP. In processing the objection application, the regional office asked the taxpayer to submit evidence supporting his appeal. As well as requests for information or evidence, it is also requested to the tax office who issued the decree. Before it was decided, the regional government sent an invitation to the taxpayer to attend a discussion on the initial research that had been conducted by the objection reviewer. After deliberations, the regional office issued a decision on the objections of taxpayers.

Settlement of tax disputes through objection mechanisms helps taxpayers to get justice more quickly and efficiently. Faster and more efficient, due to limited state finances, so until now the tax tribunal only exists in Jakarta, Yogyakarta and Surabaya. With the objection resolution mechanism, taxpayers simply go to the regional tax office. To get optimal results, taxpayers must be pro-active and submit all evidence and explanations to the review team as fully as possible. If the objection decision is satisfactory, taxpayers do not have to spend money to litigate in the tax court.

\section{Conclusion}

Process of objecting to tax disputes is classified as administrative judicial process or judicial doleansi. In this judiciary, the judge is the civil apparatus of the state tasked with examining and deciding tax disputes. The agency is designed to make it easier for taxpayers to resolve their disputes at the directorate general of taxation. This institution is one of the government's efforts to disseminate taxpayers' rights and taxpayers' duties in fulfilling their obligations.

\section{References}

[1] Teichmann, F., Falker, M. C., \& Sergi, B. S. (2020). Corruption and the circumvention of financial sanctions via the extractive industries in Dubai. Extractive Industries and Society, 7(3), 1022-1028. https://doi.org/10.1016/j.exis.2020.05.006

[2] Regulation of the Minister of Finance (PMK) No. 202/PMK,03/2015 concerning Amendment to PMK No. 9/PMK.03/2013 concerning Procedures for Exclaiming and Resolving Objections of PMK No. 9/PMK.03/2013 concerning Procedures for Exclaiming and Resolving Objections

[3] General Provisions of Taxation Law No. 6 of 1983 as amended last by Law No. 16 of 2019 
[4] Income tax law No. 7 of 1983 as amended last by Law No. 36 of 2008

[5] Value Added Tax Law No. 8 of 1983 as amended last by Law No. 42 of 2009 